\title{
Kadınların Prekonsepsiyonel Dönemdeki Sağlık Riskleri ve Sağlıklı Yaşam Biçimi Davranışlarının Belirlenmesi
}

\author{
Meral KARATAŞ 國, Zehra GÖLBAŞI [0] $^{2}$
}

Öz

Amaç: Araştırma kadınların prekonsepsiyonel dönemdeki sağlık risklerini ve sağlıklı yaşam biçimi davranışlarını belirlemek amacıyla tanımlayıcı ve kesitsel olarak yapılmıştır.

Gereç ve Yöntemler: Araştırmanın evrenini çocuk sahibi olmak amacıyla Sivas Cumhuriyet Üniversitesi Sağlık Hizmetleri Uygulama ve Araştırma Hastanesi Üremeye Yardımcı Tedavi Merkezi'ne başvuran kadınlar oluşturmuş̧tur. Örneklem 250 kadından oluşmuştur. Veriler; Tanıtıcı Özellikler Formu, Prekonsepsiyonel Risk Değerlendirme Formu ve Sağlıklı Yaşam Biçimi Davranışları Ölçeği II (SYBDÖ-II) ile toplanmıştır. Veriler bilgisayar ortamında değerlendirilmiş, istatistiksel analizde bağımsız guruplarda t testi kullanılmıştır.

Bulgular: Kadınların; \%18,4'ünün 35 yaş ve üzerinde ve \%38,4'ünün aile içi şiddet öyküsünün olması nedeniyle prekonsepsiyonel risk taşıdığı bulunmuştur. Kadınların \%42,8'inin Beden Kitle İndeksi 25 ve üzerindedir. Kadınların $\% 88,4$ 'ü düzenli egzersiz yapmamakta, \%53,2'si pasif sigara dumanına maruz kalmaktadır ve \%62'si folik asit kullanımıyla ilgili bilgi sahibi değildir. Kadınların \%33,2'sinde enfeksiyonu gösteren idrar kültürü sonucunun olması ve $\% 16,9$ 'unda anemi olması nedeniyle risk taşımaktadır. Kadınların SYBDÖ-II puan ortalamasının 128,16 19,18 olduğu, eğitim ve gelir düzeyi düşük olan, çalışmayan, yetersiz sosyal desteği ve aile içi şiddet öyküsü olan kadınların SYBDÖII puan ortalamasının anlamlı düzeyde düşük olduğu bulunmuştur $(\mathrm{p}<0,05)$.

Sonuç: Sonuç olarak çocuk sahibi olmayı düşünen kadınların prekonsepsiyonel dönemde gebelik, doğum ve doğum sonu süreci olumsuz etkileyebilecek yaş, aile içi şiddet, anemi, sigara dumanına maruz kalma gibi birçok risk faktörüne sahip oldukları söylenebilir.

Anahtar Kelimeler: Üreme sağlığı; sağlık hizmetleri; gebelik; sağlık durumu; yaşam tarzı; risk faktörleri.

\section{Determination Health Risks and Healthy Lifestyle Behaviors of Women in the Preconceptional Period}

\begin{abstract}
Aim: The study was conducted as a descriptive study to determine the health risks and healthy lifestyle behaviors in preconceptional women.

Material and Methods: The universe of study included women who wanted to have children and admitted to AssistedReproductive Treatment Center in Sivas Cumhuriyet University Health Services Practice and Research Hospital. The sample consisted of 250 women. The data were collected using Individual Characteristics Form, Preconceptional Risk Assessment Form and Health Promotion Life-Style Profile-II (HPLSP-II) and were evaluated with the SPSS 16.0 program on the computer. Independent Samples t test were used in the statistical analysis.

Results: According to the results of the study, it was found that women had risks because $18.4 \%$ were over 35 years of age and $38.4 \%$ had domestic violence. Body Mass Index of $42.8 \%$ of women is 25 and above. $88.4 \%$ of women do not exercise regularly, $53.2 \%$ are exposed to passive cigarette smoke and $62 \%$ of them do not have information about folic acid use. It was found that women had risk factors because $33.2 \%$ had urine culture result showing urinary infection and $16.9 \%$ had anemia. It was found that the mean score of HPLSP-II of women was $128.16 \pm 19.18$, the average score was found to be significantly lower for women with low education, low income, unemployed, inadequate social support, and
\end{abstract}

1 Sivas Cumhuriyet Üniversitesi Sağlık Hizmetleri Uygulama ve Araştırma Hastanesi, Sivas, Türkiye

2 Lokman Hekim Üniversitesi Sağlık Bilimleri Fakültesi Hemşirelik Bölümü, Doğum ve Kadın Hastalıkları Hemşireliği Ana Bilim Dalı, Ankara, Türkiye

*Bu çalışma, 5-8 Kasım 2017 tarihler arasında Ankara'da düzenlenen 5. Uluslararası-16. Ulusal Hemşirelik kongresinde sözlü bildiri olarak sunulmuştur. 
domestic violence narrative $(\mathrm{p}<0.05)$.

Conclusion: As a result, it can be said that women who intend to have children have many risk factors such as age, domestic violence, anemia, exposure to cigarette smoke that may negatively affect pregnancy, birth and postpartum period.

Keywords: Reproductive health; health services; pregnancy; health status; lifestyle; risk factors.

\section{Gíis}

Prekonsepsiyonel bakım; gebelik planlayan kadında gebelik sürecini etkileyecek biyomedikal, sosyal ve davranışsal risk faktörlerini belirlemek, bunların gebelik sürecindeki olumsuz etkilerini ortadan kaldırmak ya da azaltmak için gerekli bilgi ve tıbbi desteği vermek, anne adayının bu risk faktörleri kontrol altına alındıktan sonra gebeliğe başlamasını sağlamak amacıyla verilen hizmetleri kapsamaktadır (1-4). Gebelik öncesi bakım terimi, tarama ve tedavinin yanı sıra danışmanlık kavramını da içermekte ve toplum sağlığını geliştirmeyi hedeflemektedir. Böylece kronik, metabolik ve genetik birçok hastalığın neden olabileceği komplikasyonlar önlenerek anne ve bebek ölüm oranları azalt1labilmektedir (5-8).

Günümüzde, son derece yaygın ve kaliteli uygulandığında dahi prenatal bakımın, ana-çocuk sağlığını koruyup geliştirmede tek başına yeterince etkili olmadığı, gebelik öncesi bakım verildiğinde daha iyi sonuçlar elde edildiği anlaşılmıştır $(6,8,9)$. American Academy of Pediatrics (Amerikan Pediatri Akademisi) ve American College of Obstetricians and Gynecologists (Amerikan Kadın Hastalıkları ve Doğum Uzmanları Kurulu), prekonsepsiyonel danışmanlığın birincil amacının; risk taraması, tanımlanmış risklere yönelik müdahalede bulunma, eğitim ve sağlı̆̆ geliştirme olduğunu rapor etmiştir $(3,9,10)$. Yapılan çalışmalar da prekonsepsiyonel danışmanlığın anne, çocuk, aile ve toplum sağlığını geliştirmek ve sağlık bakım maliyetlerini azaltmak açısından birçok yararını ortaya koymaktadır. Prospektif bir çalışma, çocuk sahibi olmak isteyen çiftlerin prekonsepsiyonel beslenme durumunun fertilite sonuçları, perinatal sağlık ve bebeğin uzun süreli sağlığı üzerinde etkili olduğunu göstermiştir (11). Yapılan başka bir çalışmada, prekonsepsiyonel dönemdeki kadınların $\% 95$ 'inin en az bir risk taşıdığ $1, \% 52$ 'sinin tıbbi ve üreme ile ilgili bir problem yaşadığ $1, \% 25$ 'inin hepatit taşıyıcısı olduğu, \%17'sinin bağımlılık yapıcı madde ve alkol kullandığı ve \%54'ünün beslenme yönünden riskli olduğunu ortaya koymuştur (12). Johnson ve ark.'nın (1) çalışmasında ise prekonsepsiyonel dönemdeki kadınlarda folik asit kullanımı bilincinin yeterli olmadığı ve geliştirilmesi gerektiği vurgulanmaktadır. Diğer taraftan konsepsiyon öncesi uygun eğitim ve danışmanlık hizmeti alan kadınların, düzenli antenatal kontrole gitme alışkanlığı edindikleri ve gebeliklerini daha sağlıklı geçirdikleri kanıtlanmıştır $(13,14)$.

Prekonsepsiyonel bakımın amac1; maternal ve fetal sağlığı tehdit eden riskleri kontrol altına almak/önlemek, sağlığı korumak ve desteklemek, gebelik üzerine etkisi olabilecek alışkanlıkları, sağlık davranışları ve sosyal yaşamla ilgili olumsuzlukları tanımlamak ve ortadan kaldırılmasına yönelik gerekli müdahaleleri başlatmaktır (1,14-16). Özellikle hemşireler risk faktörlerinin tanımlanmasında ve maternal / fetal sonuçları iyileştirecek sağlık davranışlarının geliştirilmesinde önemli rolleri olan sağlık çalışanı olarak vurgulanmaktadır (16). Ülkemizde de 2010 yılında yayınlanan Hemşirelik Yönetmeliği' ne göre de, çiftlere gebelik öncesi eğitim ve danışmanlık yapmak Kadın Sağlığı ve Hastalıkları Hemşiresi'nin görev, yetki ve sorumlulukları arasındadır (17). Ülkemizde prekonsepsiyonel hizmetler yaygın olmadığı için, gebelik öncesi dönemde çocuk sahibi olmak isteyen çiftlerin sağlık durumunu, üremeyi etkileme boyutuyla değerlendiren çalışmaların sayısı oldukça sınırlıdır (10). $\mathrm{Bu}$ nedenle çalışma gebelik planlayan kadınlarda prekonsepsiyonel dönemde var olan risk faktörleri ve sağlıklı yaşam biçimi davranılarını belirlemek ve böylece prekonsepsiyonel bakımın önemine dikkat çekmek amacıyla yapılmıştır.

\section{GEREÇ VE YÖNTEMLER}

Araştırmanın Tipi: Araştırma tanımlayıcı ve kesitsel tipte yapılmıştır.

Araştırmanın Evreni ve Örneklemi: Araştırma Sivas Cumhuriyet Üniversitesi Sağlık Hizmetleri Uygulama ve Araştırma Hastanesi Üremeye Yardımcı Tedavi Merkezi'nde yapılmıştır. Merkeze hem çocuk sahibi olmak isteyen çiftler, hem de infertilite tanısı almış ve tedavi sürecinde olan çiftler başvurmaktadır. Merkeze tekrarlı başvurular olduğu için bir yılda başvuran kadın sayıs1 belirlenememiştir. Veriler 16.11.2016 ile 31.12.2016 tarihleri aradında toplanmıştır. Bu tarihler arasında merkeze ilk kez başvuran, araştırmaya dahil edilme kriterlerini karşılayan ve gönüllü olduğuna dair yazılı onam veren 250 kadın örnekleme dahil edilmiştir. Araştırmaya dahil edilme kriterleri; çocuk sahibi olma isteği ile ilk kez merkeze başvurma, infertilite tanısı almamış olma ve infertilite tedavi sürecinde olmama olarak belirlenmiştir. Ulaşılan örneklem sayısının gücü $\mathrm{G}$ Power 3.1.9.2. programında post hoc t testi ile belirlenmiş ve 0,30 etki büyüklüğünde ve 0,05 hata payı ile 0,99 olarak bulunmuştur.

Verilerin Toplanması ve Veri Toplama Araçları: Araştırmanın verileri Tanıtıcı Özellikler Formu, Prekonsepsiyonel Risk Değerlendirme Formu ve Sağlıklı Yaşam Biçimi Davranışları Ölçeği-II (SYBDÖ-II) ile toplanmıştır. Tanıtıcı Özellikler Formu araştırmacılar tarafından hazırlanmış olup, kadınların sosyodemografik özelliklerini ve mevcut sağlık durumunu tanımlamak amacıyla oluşturulan 29 soruyu içermektedir. Prekonsepsiyonel Risk Değerlendirme Formu ilgili literatür doğrultusunda (2,7-10,11,18) araştırmacılar tarafından hazırlanmıştır. Formda gebeliğin oluşumunu ve gebeliğin gidişini etkileyebileceği için, gebelik öncesi dönemde kadında değerlendirilmesi gereken risk faktörleri sıralanmıştır. Hazırlanan taslak form; kadın hastalıkları ve doğum alanında uzman 5 tıp doktoru, infeksiyon hastalıkları alanında uzman bir tıp doktoru ve doğum ve kadın hastalıkları hemşireliği alanında uzman 5 öğretim üyesinin görüşüne sunulmuş ve uzmanların önerileri doğrultusunda formda gerekli düzenlemeler yapılarak son hali verilmiştir.

Sağlıklı Yaşam Biçimi Davranışları Ölçeği-II (Health Promotion Life-Style Profile-II), Walker ve arkadaşları tarafından 1987 'de geliştirilmiştir. Ölçek bireyin sağlıklı 
yaşam biçimi ile ilişkili olarak sağlığı geliştiren davranışlarını ölçmektedir. Ölçeğin Türkçe geçerlik ve güvenirlik çalışması Bahar ve arkadaşları (19) tarafından yapılmıştır. Ölçek toplam 52 maddeden oluşmuş olup 6 alt faktörü vardır. Sağlık sorumluluğu, fiziksel aktivite, beslenme, ruhsal gelişim, kişilerarası ilişkiler ve stres yönetimi ölçeğin alt gruplarıdır. Ölçeğin tüm maddeleri olumludur. Ölçeğin Cronbach Alpha katsayısı 0,92 olup yüksek güvenirlik derecesine sahiptir. Ölçeğin alt boyutlarının güvenirlik katsayıları ise; Sağlık Sorumluluğu 0,77, Fiziksel Aktivite 0,79, Beslenme 0,68, Manevi Gelişim 0,79, Kişilerarası İlişkiler 0,80, Stres Yönetimi 0,64 tür. Derecelendirme dörtlü likert şeklindedir. Hiçbir zaman (1), bazen (2), sık sık (3), düzenli olarak (4) olarak puanlandırılmaktadır. Ölçeğin tamamı için en düşük puan 52, en yüksek puan 208'dir. Ölçeğin toplam puanı sağlıklı yaşam biçimi davranışları puanını vermektedir. Puanın yüksek olması sağlıklı yaşam biçimi davranışlarının yüksek olduğunu göstermektedir.

Araştırmanın Etik Boyutu: Araştırmanın uygulama sürecinden önce, Sivas Cumhuriyet Üniversitesi Girişimsel Olmayan Klinik Araştırmalar Etik Kurul Başkanlığı'ndan etik kurul onayı (Karar No: 2016-05/05; Tarih:27.05.2016), Sivas Cumhuriyet Üniversitesi Sağlık Hizmetleri Uygulama ve Araştırma Hastanesi Başhekimliği'nden uygulama izni alınmıştır (Karar No: 044; Tarih: 15.11.2016). Araştırma sürecinde araştırma ve yayın etiği ilkelerine uygun olarak davranılmış, araştırma süreci Helsinki Deklerasyonu ilkelerine uygun olarak yürütülmüştür. Araştırmada yer alan kadınların kimlik bilgileri gizlilik ilkesine uygun olarak alınmamış, araştırmaya katılmaya gönüllü olduklarına dair yazılı onamları alınmıştır. Veri toplama formları araştırmacı tarafından yüz yüze görüşme yöntemi ile toplanmış olup, laboratuar sonuçları hasta dosyasından alınmıştır.

\section{İstatistiksel Analiz}

Veriler bilgisayar ortamında SPSS 16.0 programında değerlendirilmiştir. Sayımla elde edilen veriler frekans dağılımı olarak (prekonsepsiyonel riskler, eğitim düzeyi, çalışma durumu vb.) ölçümle elde edilen veriler (Sağlıklı Yaşam Biçimi Davranışları Ölçeği II puanı, yaş vb.) ortalama ve standart sapma olarak gösterilmiştir. SağlıklıYaşam Biçimi Davranışları Ölçeği II puanının normal dağılıma uygunluğu Kolmogorov Smirnov testi ile değerlendirilmiştir. Kadınların bazı özeliklerine göre SYBDÖ-II puanı karşılaştırılırken bağımsız gruplarda $\mathrm{t}$ testi kullanılmıştır. Anlamlılık düzeyi $\mathrm{p}<0,05$ olarak kabul edilmiştir.

\section{BULGULAR}

Araştırmaya katılan kadınların yaş ortalaması 29,31 \pm 5,90 (En düşük:19, En yüksek:49) olup, \%52,8'inin 1929 yaş grubunda, \%33,6'sının üniversite mezunu, \%71,2'sinin çalışmadığ1, \%75,6'sının il merkezinde yaşadığı, \%42,8'inin düşük gelir düzeyinde ve $\% 75,2$ 'sinin çekirdek aile tipine sahip olduğu belirlenmiştir. Kadınların ortalama evlilik süresinin $5,54 \pm 4,58$ y1l, ortalama gebelik sayısinın 1,20 $\pm 1,28$,

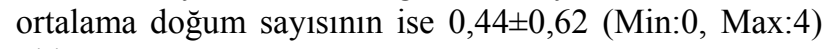
olduğu saptanmıştır.

Kadınların bireysel/ailesel özellikleri, ev ortamı ve aile ilişkilerine yönelik prekonsepsiyonel risk faktörü taşıma durumuna göre dağılımı Tablo 1'de gösterilmiştir. Kadınların \%18,4'ünün 35 yaş ve üzerinde olma, \%21,6'sının ilköğretim ve altı eğitim düzeyine sahip olma, \%24,4'ünün ilçe veya köyde yaşama, \%7,6'sının akraba evliliği yapma, \%13,2'nin gebeliği olumsuz etkileyecek ortamda çalışma ve $\% 42,8$ 'inin düşük gelir düzeyine sahip olma nedenlerinden dolayı prekonsepsiyonel risk faktörü taşıdığı belirlenmiştir. Ayrıca kadınların \%38,4'ünün aile içi şiddet öyküsünün olması, \%18,4'ünün sosyal desteğinin yetersiz olması ve \%8,4'ünün ise evde aşısız ve kontrolsüz evcil hayvan beslemesi nedeniyle prekonsepsiyonel risk taşıdığ saptanmıştır.

Tablo 1. Kadınların bireysel/ailesel özellikleri, ev ortamı ve aile ilişkilerine yönelik prekonsepsiyonel risk faktörü taşıma durumu $(\mathrm{n}=250)$

\begin{tabular}{|l|c|c|}
\hline \multirow{2}{*}{ Risk Faktörü } & \multicolumn{2}{c|}{ Risk } \\
\cline { 2 - 3 } & $\begin{array}{c}\text { Var } \\
\text { Sayı (\%) }\end{array}$ & $\begin{array}{c}\text { Yok } \\
\text { Sayı (\%) }\end{array}$ \\
\hline 35 yaş ve üzerinde olma & $46(18,4)$ & $204(81,6)$ \\
\hline $\begin{array}{l}\text { Eğitim durumu (İlköğretim ve altı } \\
\text { eğitim düzeyine sahip olma ) }\end{array}$ & $54(21,6)$ & $196(78,4)$ \\
\hline $\begin{array}{l}\text { Gebeliği olumsuz etkileyecek } \\
\text { çalışma ortamı (Radyasyon, } \\
\text { enfeksiyon vb.) }\end{array}$ & $33(13,2)$ & $217(86,8)$ \\
\hline Düşük gelir düzeyine sahip olma & $107(42,8)$ & $143(57,2)$ \\
\hline Akraba evliliği & $19(7,6)$ & $231(92,4)$ \\
\hline Yaşadığı yer ( İlçe veya köy ) & $61(24,4)$ & $189(75,6)$ \\
\hline $\begin{array}{l}\text { Ailede mental retardasyonlu birey } \\
\text { olması }\end{array}$ & $31(12,4)$ & $219(87,6)$ \\
\hline $\begin{array}{l}\text { Ailede konjenital anomalisi olan } \\
\text { birey olması }\end{array}$ & $35(14,0)$ & $215(86,0)$ \\
\hline $\begin{array}{l}\text { Ev ortamında kimyasal maddeye } \\
\text { maruziyet* }\end{array}$ & $203(81,2)$ & $47(18,8)$ \\
\hline $\begin{array}{l}\text { Aile içi şiddet öyküsü olması } \\
\text { Yetersiz sosyal destek (Bireyin } \\
\text { kendi subjektif ifadesine göre) }\end{array}$ & $96(38,4)$ & $154(61,6)$ \\
\hline $\begin{array}{l}\text { Evde aşısız ve kontrolsüz evcil } \\
\text { hayvan besleme }\end{array}$ & $21(8,4)$ & $229(91,6)$ \\
\hline (Cam/kumaş boyama; iç/dı̧ cephe boyaları; vernik ve cilalar; böcek ve hasere ilaçları; & $204(81,6)$ \\
\hline
\end{tabular}

firın temizleyici; gümüş parlatıcı, vb.)

Kadınların mevcut sağlık durumu ve sağlık davranışlarına ilişkin risk faktörü taşıma durumuna göre dağılımı Tablo 2'de gösterilmiştir. Buna göre kadınların \%42,8'inin BKİ'nin 25 ve üzerinde olduğu, \%88,4'ünün düzenli egzersiz yapmadığı, \%13,2'sinin halen sigara içtiği, \%53,2'sinin ise pasif sigara dumanına maruz kaldığ bulunmuştur. Kadınların \%71,2'sinin ağız ve diş sağlığı kontrolüne gitmemesi, \%62'sinin folik asit kullanımına ilişkin bilgilerinin olmaması, \%58,4'ünün çiğ et yediği ya da çiğ ete temas etmesi ve \%31,6'sının vitamin, zayıflama çayı, bitkisel ürün ya da herhangi başka bir ilaç dışı takviye kullanması nedeni ile prekonsepsiyonel risk taşıdığ1 belirlenmiştir. Kadınların; \%24'ünün sürekli kullanması gereken ilacinın olması, \%33,2'sinde enfeksiyonu gösteren idrar kültürü sonucunun olmas1, \%16,9'unda anemi, \%13,0'de HbsAg pozitifliği ve \%79,2'sinin tetanoz ve hepatit B bağışıklığının olmaması nedeniyle risk taşıdığ1 görülmüştür. 
Tablo 2. Kadınların mevcut sağlık durumu ve sağlık davranışlarına ilişkin risk faktörü taşıma durumu $(\mathrm{n}=250)$

\begin{tabular}{|c|c|c|}
\hline \multirow[b]{2}{*}{ Risk Faktörü } & \multicolumn{2}{|c|}{ Risk } \\
\hline & $\begin{array}{c}\text { Var } \\
\text { Sayı }(\%)\end{array}$ & $\begin{array}{c}\text { Yok } \\
\text { Sayı }(\%)\end{array}$ \\
\hline BKİ'nin 25 ve üzerinde olmas1 & $107(42,8)$ & $143(57,2)$ \\
\hline BKİ'nin 18.5 altında olmas1 & $7(2,8)$ & $243(97,2)$ \\
\hline Düzenli egzersiz yapmama & $221(88,4)$ & $29 \quad(11,6)$ \\
\hline Sigara içme & $33(13,2)$ & $217(86,8)$ \\
\hline $\begin{array}{l}\text { Pasif sigara dumanına maruz } \\
\text { kalma }\end{array}$ & $133(53,2)$ & $117(46,8)$ \\
\hline $\begin{array}{l}\text { Ağız ve diş sağlığı sorunu olması } \\
\text { (çürük diş, eksik diş, diş eti } \\
\text { iltihabi vb.) }\end{array}$ & $173(69,2)$ & $77(30,8)$ \\
\hline $\begin{array}{l}\text { Ağız ve diş sağlı̆̆ kontrolünün } \\
\text { olmaması }\end{array}$ & $178(71,2)$ & $72(28,8)$ \\
\hline $\begin{array}{l}\text { Folik asit kullanmama/ folik asit } \\
\text { kullanması gerektiğini bilmeme }\end{array}$ & $155(62,0)$ & $95(38,0)$ \\
\hline Çiğ et yeme / çiğ ete temas & $146(58,4)$ & $104(41,6)$ \\
\hline $\begin{array}{l}\text { Reçetesiz/danışmadan ilaç } \\
\text { kullanma alışkanlığının olması }\end{array}$ & $90(36,0)$ & $160(64,0)$ \\
\hline $\begin{array}{l}\text { Vitamin, zayıflama çayı, bitkisel } \\
\text { ürün, ya da herhangi başka bir } \\
\text { ilaç dişı takviye kullanma } \\
\text { alışkanlığ }\end{array}$ & $79(31,6)$ & $171(68,4)$ \\
\hline $\begin{array}{l}\text { Sürekli kullanmas1 gereken ilaç } \\
\text { olması }\end{array}$ & $60(24,0)$ & $190(76,0)$ \\
\hline $\begin{array}{l}\text { Enfeksiyonu gösteren idrar } \\
\text { kültürü sonucu }\end{array}$ & $83(33,2)$ & $167(66,8)$ \\
\hline $\begin{array}{l}\text { Anemi }(\leq 11 \mathrm{~g} / \mathrm{dl} \text { hemoglobin } \\
\text { değeri) }(\mathrm{n}=225)\end{array}$ & $38(16,9)$ & $187(83,1)$ \\
\hline $\begin{array}{l}\text { Anormal Pap Smear sonucu }(\mathrm{n}= \\
158)\end{array}$ & $11(7,0)$ & $147(93,0)$ \\
\hline HbsAg pozitif olması $(n=77)$ & $10(13,0)$ & $67(87,0)$ \\
\hline $\begin{array}{l}\text { Kan grubunun anne adayında } \\
\text { negatif baba adayında pozitif } \\
\text { olmas1 } \\
(\mathrm{n}=242)\end{array}$ & $19(7,9)$ & $223(92,1)$ \\
\hline Tetanoz bağışıklığının olmaması & $198(79,2)$ & $52(20,8)$ \\
\hline Hepatit B bağışıklığının olmaması & $198(79,2)$ & $52(20,8)$ \\
\hline
\end{tabular}

Araştırmaya katılan kadınların geçmiş obstetrik ve jinekolojik öyküsüne ilişkin risk faktörü taşıma durumuna göre dağılımı Tablo 3'te gösterilmiştir. Buna göre kadınların \%12'sinde sezaryen, \%6'sında erken doğum, \%4,4'ünde düşük doğum ağırlığı (2500gr. $\downarrow)$ öyküsü olmas1 ve \%20'sinde ise bir önceki gebelikten sonra geçen sürenin 2 yıl veya daha az olması nedeni ile prekonsepsiyonel risk taşıdığı belirlenmiştir. Ayrıca kadınların \%59,2'sinin jinekolojik hastalık öyküsü olduğu, \%26,8'inin geçirilmiş uterin cerrahi öyküsü, $\% 70$ 'inin vajinal enfeksiyonu gösteren akıntı ve $\% 37,2$ 'sinin ise menstruasyon düzensizliğinin olması nedeniyle prekonsepsiyonel risk taşıdıkları belirlenmiștir. Araştırmaya katılan kadınların Sağlıklı Yaşam Biçimi Davranışları Ölçek-II puan ortalamaları Tablo 4'te gösterilmiştir. Buna göre sağlik sorumluluğu ölçek puan ortalamasinın 21,54 $\pm 4,59$, fiziksel aktivite puan ortalamasinın $13,21 \pm 4,32$, beslenme puan ortalamasının $21,30 \pm 4,18$, manevi gelişim puan ortalamasının $26,90 \pm 4,55$, kişiler arası ilişkiler puan ortalamasının $26,08 \pm 4,60$, stres yönetimi puan ortalamasının $19,10 \pm 3,96$ ve ölçek toplam skorunun ise $128,16 \pm 19,18$ olduğu bulundu.

Tablo 3. Kadınların geçmiş obstetrik ve jinekolojik öyküsüne ilişkin risk faktörü taşıma durumu $(\mathrm{n}=250)$

\begin{tabular}{|l|lr|rc|}
\hline \multirow{2}{*}{\multicolumn{1}{|c|}{ Risk Faktörüi }} & \multicolumn{4}{c|}{ Risk } \\
\cline { 2 - 6 } & \multicolumn{3}{|c|}{ Var } & \multicolumn{2}{c|}{ Yok } \\
& Sayı & \% & Sayı & \% \\
\hline Sezaryen & 30 & 12,0 & 220 & 88,0 \\
\hline $\begin{array}{l}\text { Erken doğum (37 haftadan } \\
\text { önce) }\end{array}$ & 15 & 6,0 & 235 & 94,0 \\
\hline $\begin{array}{l}\text { Düşük doğum ağırlığı } \\
\text { (2500gr. } \downarrow \text { ) }\end{array}$ & 11 & 4,4 & 239 & 95,6 \\
\hline $\begin{array}{l}\text { Bir önceki gebelikten sonra } \\
\text { geçen süre 2 yıl ve az olması }\end{array}$ & 50 & 20,0 & 200 & 80,0 \\
\hline Jinekolojik hastalık & 148 & 59,2 & 102 & 40,8 \\
\hline $\begin{array}{l}\text { Geçirilmiş uterin cerrahi } \\
\text { (myomektomi, konizasyon } \\
\text { vb.) }\end{array}$ & 67 & 26,8 & 183 & 73,2 \\
\hline $\begin{array}{l}\text { Vajinal enfeksiyonu gösteren } \\
\text { akıntı }\end{array}$ & 175 & 70,0 & 75 & 30,0 \\
\hline Menstrasyon düzensizliği & 93 & 37,2 & 157 & 62,8 \\
\hline
\end{tabular}

Tablo 4. Kadınların sağlıklı yaşam biçimi davranışları ölçeği-II puan ortalaması (n=250)

\begin{tabular}{|l|c|c|c|c|}
\hline & $\begin{array}{c}\text { Ölçekten alınabilecek } \\
\text { Minimum ve maksimum } \\
\text { Alt Boyutlar }\end{array}$ & $\mathbf{X} \pm$ SD $^{*}$ & Min & Max \\
& $9,00-36,00$ & $21,54 \pm 4,59$ & 11,00 & 33,00 \\
\hline Sağlik sorumluluğu & $8,00-32,00$ & $13,21 \pm 4,32$ & 8,00 & 30,00 \\
Fiziksel aktivite & $9,00-36,00$ & $21,30 \pm 4,18$ & 9,00 & 31,00 \\
Beslenme & $9,00-36,00$ & $26,90 \pm 4,55$ & 12,00 & 36,00 \\
Manevi gelişim & $9,00-36,00$ & $26,08 \pm 4,60$ & 12,00 & 36,00 \\
Kişilerarası ilişkiler & $8,00-32,00$ & $19,10 \pm 3,96$ & 10,00 & 32,00 \\
Stres yönetimi & $52,00-208,00$ & $128,16 \pm 19,18$ & 83,00 & 182,00 \\
\hline Toplam & & & & \\
\end{tabular}


Tablo 5. Kadınların bazı özelliklerine göre sağlıklı yaşam biçimi davranışları ölçeği-II puan ortalaması $(n=250)$

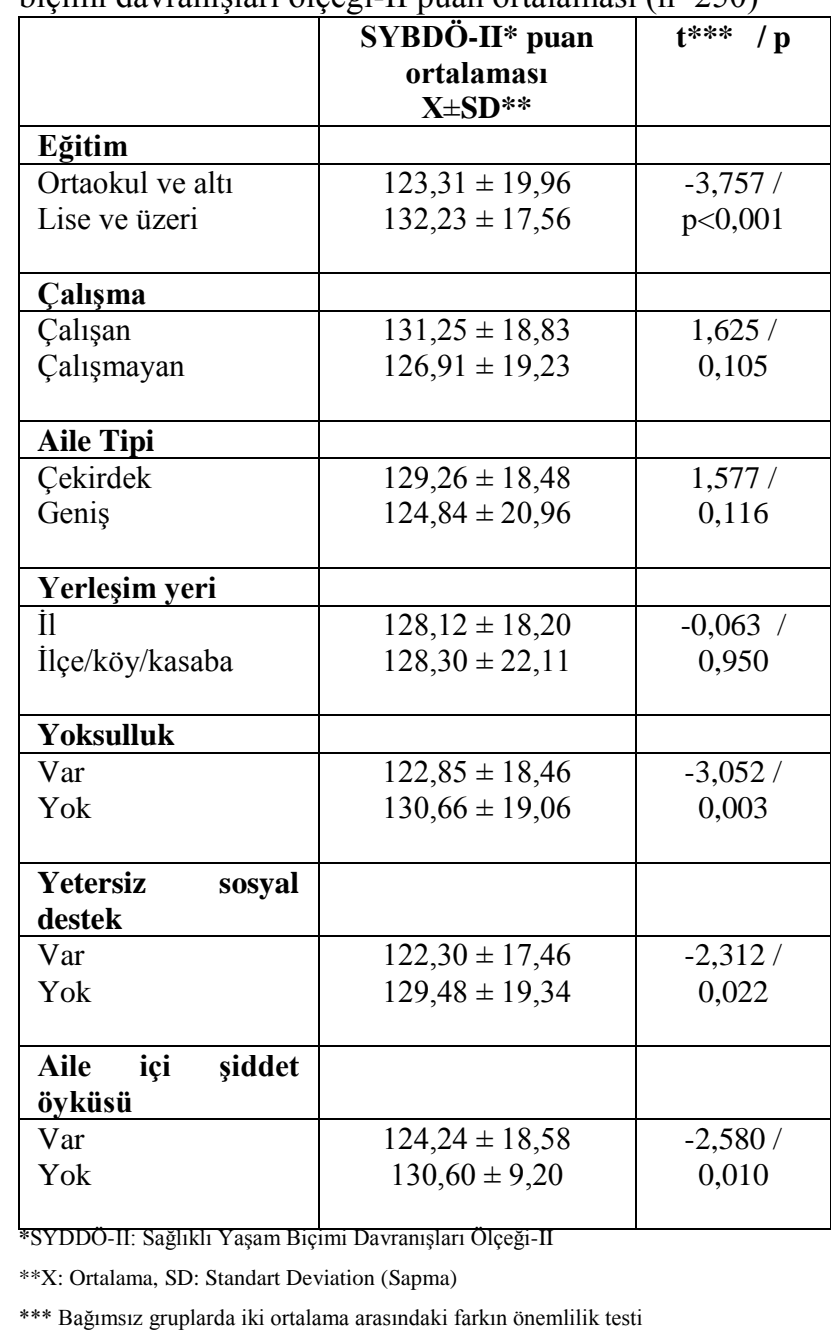

Araştırmaya katılan kadınların bazı özelliklerine göre Sağlıklı Yaşam Biçimi Davranışları Ölçek-II puan ortalamalarının dağılımı Tablo 5'te gösterilmiștir. Eğitim düzeyi lise ve üzeri $(132,23 \pm 17,56 ; 123,31 \pm 19,96)$ ve sosyal desteği yeterli olan $(129,48 \pm 19,34 ; 122,30 \pm 17,46)$, aile içi şiddet öyküsü $(130,60 \pm 19,20 ; 124,24 \pm 18,58)$ ve yoksulluk sinırı altında olmayan $(130,66 \pm 19,06$; $122,85 \pm 18,46)$ kadınların SYBDÖ-II puan ortalamasının daha yüksek ve gruplar arasındaki farkın istatistiksel olarak anlamlı olduğu bulunmuştur $(\mathrm{p}<0,05)$.

\section{TARTIŞMA}

Türkiye Nüfus ve Sağlık Araştırması (TNSA) 2018 sonuçları kadınların önemli bir oranının bebek ve çocuk sağlığını etkileyen riskli doğurganlık davranışlarına sahip olduğunu göstermektedir (20). Bu risk faktörlerinin prekonsepsiyonel dönemde saptanması hem ortadan kaldırılması hem de kontrol altında tutulması açısından önemlidir.

$\mathrm{Bu}$ araştırmada kadınların \%18,4'ünün 35 yaş ve üzerinde olduğu ve gebelik planladığı saptanmıştır. Literatürde 18 yaş altı ve 35 yaş üstü gebelikler riskli gebelik olarak kabul edilmektedir. İleri yaştaki gebeliklerde perinatal mortalite ve morbidite oranlarında artış olduğu ve gebelik komplikasyonlarının daha sık görüldüğü belirtilmektedir $(2,8,10)$. Türkiye'de yapılmış bazı çalışmalarda 35 yaş ve üzeri gebeliklerin \%10,5-18,6 arasında değiştiği görülmektedir $(21,22)$. Bu durum kadının eğitim düzeyinin artması ve çalışma yaşamında daha fazla yer almasından dolayı gebeliklerin ileri yaşlara ertelendiğini düşündürmektedir.

$\mathrm{Bu}$ araştırmada kadınların \%21,6'sının ilköğretim ve altı eğitim düzeyinde ve \%42,8'inin düşük gelir grubunda yer aldığı ve bu açıdan prekonsepsiyonel dönemde risk taşıdıkları belirlenmiştir. Kadının gelir ve eğitim durumu; sağlıklı doğurganlık hakkında bilgi sahibi olma, gerekli sağlık hizmetine ulaşma ve kullanmasını etkileyen faktörler arasında yer almaktadır (22-24). Literatürde düşük eğitim ve sosyoekonomik düzeye sahip olmanın, gebelikte yol açabileceği sorunlar açısından prekonsepsiyonel dönemde risk faktörleri arasında olduğu belirtilmektedir (24,25). Ailenin sosyoekonomik durumunun gebelik ve doğum komplikasyonları üzerinde etkili olduğu, özellikle düşük sosyoekonomik koşullara sahip kadınlarda doğum öncesi bakım alma oranının yetersiz, antenatal stres, anksiyete ve depresif belirtilerin daha yaygın olduğu, ağı ve diş sağlığı hizmetlerinden yararlanmanın düşük olduğu yapılan çalışmalarda belirtilmiştir $(22,26)$.

Aile içi kadına yönelik şiddet bireyde fiziksel ve ruhsal sorunlara, üretkenlik kaybına, birey ve ailenin yaşam kalitesinin düşmesine, aile bütünlüğünün bozulmasına ve gebelik komplikasyonlarına (erken doğum, düşük, erken membran rüptürü vb.) neden olduğu için prekonsepsiyonel dönemde risk faktörü olarak görülmektedir $(27,28)$. Ek olarak sosyal destek eksikliği de kadınlarda stresi artıran, maternal ve fetal sağlığ olumsuz etkileyen bir durumdur (29). Çalışmamızda yer alan kadınların \%18,4'ünün yetersiz sosyal desteğe sahip oldukları, \%38,4'ünün aile içi şiddet öyküsü olması nedeniyle risk taşıdıkları belirlenmiştir. Yapılan çalışmalarda da emosyonel desteği düşük olan kadınların daha fazla doğum korkusu ve stres yaşadığı ve bu durumun nöral tüp defekti riskini artırdığı; yetersiz doğum öncesi bakım aldıkları ve sosyal desteğe daha fazla ihtiyaç duydukları bulunmuştur (27-29).

Bu çalışmada kadınların \%42,8'inin Beden Kütle İndeksi (BKİ) 25 ve üzerinde ve \%2,8'inin ise BKI'si 18,5 ve altında olması nedeniyle maternal kilo açısından prekonsepsiyonel dönemde risk taşıdıkları saptandı. Ülkemizde Sağlık Bakanlığı verilerine göre, kadınlarda obezite görülme oranı \%41,0'dır. Maternal kilo ve beslenme gebelik sonuçlarının değiştirilebilir önemli belirleyicilerinden biridir (30,31). Gebelik öncesi obezite maternal, neonatal morbidite ve mortalite için bağımsız bir risk faktörü olup, obez gebelerin normal kilolu gebelere göre tıbbi-obstetrik komplikasyon (preeklampsi, hipertansiyon, gestasyonel diyabet, spontan abortus) yaşama riski daha yüksektir (32). Çalışmamızın sonuçlarına göre hem anne hem de bebek için komplikasyon riskini artıran obezitenin yaygın bir sağlık sorunu olduğu, kadınların büyük bir kısmının maternal kilo açısından prekonsepsiyonel dönemde risk altında oldukları söylenebilir.

Bu araştırmada kadınların \%84,4'ünün düzenli egzersiz yapmadıkları için risk taşıdıkları saptanmıştır. Kadınların gebeliğe sağlıklı başlamaları ve gebeliklerinin daha sağlıklı sürmesi için prekonsepsiyonel dönemden başlayarak orta yoğunlukta düzenli egzersiz yapmaları önerilmektedir (2,31,33). Buna karşın çalışma 
sonucumuzu destekler nitelikte yapılan diğer çalışmalarda kadınlarda egzersiz yapma alışkanlığının oldukça düşük olduğu görülmektir $(22,31)$.

$\mathrm{Bu}$ çalışmada kadınların \%13,2'sinin sigara içmesi $\% 53,2$ 'sinin ise pasif sigara dumanına maruz kalması nedeniyle risk taşıdıkları tespit edilmiştir. Ülkemizde yapılan çalışmalar gebelikte sigara kullanımı ve gebelikte sigara dumanına maruziyetin önemli bir sorun olduğunu göstermektedir $(22,28,34)$. Bu nedenle gebelik planlayan çiftlere yönelik sigarayı bırakma eğitimleri prekonsepsiyonel danışmanlık hizmetlerinin önemli bir ögesi olmalıdır.

Bu çalışmada kadınların \%69,2'sinin ağız ve diş sağlığ 1 sorunu olması (çürük diş, diş eti iltihabi vb.) ve $\% 71,2$ 'sinin ağız ve diş sağlığı kontrolü olmaması nedeniyle risk altında oldukları belirlenmiştir. Ağız ve diş sağlığı sorunları kadının yaşam kalitesini düşürmesi ve anne/bebek sağlığı açısından riskli durumlar (erken doğum, preeklempsi gibi) ortaya çıkarması nedeniyle önemlidir. Ayrıca prekonsepsiyonel dönemde önlenebilir veya tedavi edilebilir bir risk faktörü olarak ele alınmaktadır (26,36). Yapılan bir çalışmada çürük ve/veya protez gerektiren eksik dişe bağlı olarak gebelerin \%90,7'sinin, dişeti hastalığı nedeniyle de \%56,9'unun tedavi gereksinimi olduğu belirlenmiştir (26) $\mathrm{Bu}$ nedenle koruyucu ağız ve diş sağlığı hizmetlerine öncelik verilmesi, kadınların gebelik öncesi ağız ve diş muayenelerinin yapılması diş ve dişeti hastalıklarının prevalansında azalma sağlanması ve kadınların daha sağlıklı bir gebelik dönemi geçirmeleri açısından önem taşımaktadır.

$\mathrm{Bu}$ araştırmada kadınların \%62'sinin folik asit kullanmama/ folik asit kullanması gerekliliğini bilmediği saptanmıştır. Prekonsepsiyonel dönemde kadına sağlanan folik asit desteği, doğum defektlerinin (nöral tüp defeklerini ve konjenital anomaliler) önlenmesinde önemli bir faktördür (37,38). Bu konuda yapılmış çok sayıda çalışma olmamakla birlikte, Hollanda'da yapılan bir çalışmada kadınların \%32'nin gebelik öncesi folik asit kullanmadığ bulunmuştur (9). Buna göre çalışmamızdaki kadınlar arasında gebelik öncesi folik asit kullanımı konusunda bilgi eksikliğinin daha yüksek olduğu söylenebilir.

Gebelik planlayan kadınların prekonsepsiyonel dönemde reçetesiz ilaç kullanmamaları, ilaç almadan önce mutlaka hekime danışmaları ve gebe kalma olasılıkları bulunduğu yönünde hekime bilgi vermeleri konusunda eğitilmeleri önemlidir. Yapılan çalışmalarda ilaca ve diğer kimyasal ajanlara bağlı konjenital malformasyon oranının \%1-3 olduğu gösterilmiştir (13,38-40). Ockhuijsen ve ark.'nın (9) çalışmasında kadınların \%48'inin reçetesiz ilaç kullandığı ve bu açıdan prekonsepsiyonel dönemde risk taşıdıkları tespit edilmiştir. Özellikle gebeliğin erken dönemde tespit edilememesi, gebelikten önce var olan veya gebelikte ortaya çıkan hastalıklar ve gebeliklerin plansız olması bu risk faktörünü daha da arttırmaktadır. Türkiye'de prekonsepsiyonel dönemde yapılmış olan çalışmaların sınırlı olması ve yapılmış olan çalışmalarda da bu konunun ele alınmaması, bu konunun gözden kaçırılan bir risk faktörü olduğunu göstermektedir.

Bu çalışmada kadınların \%24'ünün sürekli kullandıkları bir ilaç (antidepresan, troid hormonu vb) \%36'sının reçetesiz/danışmadan ilaç kullanma alışkanlığı, \%31,6'sının ise vitamin, zayıflama çayı, bitkisel ürün, ya da herhangi başka bir ilaç dışı takviye kullanma alışkanlığı olduğu ve bu açıdan prekonsepsiyonel risk taşıdıkları saptanmıştır. Gebelik düşünen tüm kadınların ilaç kullanımı açısından taranması, sürekli ilaç kullanılması gereken durumlarda (diyabet, depresyon, hipertansiyon gibi) mümkün olan en düşük doza geçilmesi veya kullanılan ilacın teratojen olmayan ile değiştirilmesi anne ve fetüs sağlığı açısından oldukça önemlidir $(13,40)$. Bitkisel ilaçların veya çayların gebelerde ve süt veren annelerde kullanılmasının sakıncalı olduğu bildirilmektedir (38). Gebe ve emzikli kadınlarla çalışma yapmanın riskli olması nedeniyle bitkisel çayların yan etkilerinin tam olarak bilinmemesi konunun farklı bir boyutunu göstermekte, prekonsepsiyonel dönemdeki kadınların bu konuda bilgilendirilmesini gerekli kılmaktadır.

Bu çalışmada kadınların laboratuvar sonuçları üriner / vajinal enfeksiyon, Rh uyumsuzluğu ve bağışıklamanın olmaması gibi nedenlerle preonsepsiyonel risk taşıdıklarını göstermiştir. Prekonsepsiyonel dönemde kadın tam bir fizik muayeneden geçirilmeli, gerekli laboratuar tetkikleri istenerek prekonsepsiyonel dönemde tespit edilebilecek risklere (üriner sistem enfeksiyonu, anemi, Rh uygunsuzluğu gibi) yönelik değerlendirme yapılmalı ve anne ve bebek sağlığını tehdit etmeden bu riskler kontrol altına alınmalıdır $(24,38,41)$.

Prekonsepsiyonel dönemde ve gebelik sürecinde kadının sağlık davranışları, gebeliği ve gebelik sonuçlarını ayrıca yenidoğanın sağlığını doğrudan etkilemektedir (42). Bu araştırmada kadınların SYBDÖ-II toplam puan ortalamasının 128,16 $\pm 19,18$ olduğu; eğitim ve gelir düzeyi düşük olan, çalışmayan, yetersiz sosyal desteği ve aile içi şiddet öyküsü olan kadınların SYBDÖ-II puan ortalamasının anlamlı düzeyde düşük olduğu bulunmuştur $(p<0,05)$. Türkiye'de kadınların sağlıklı yaşam biçimi davranışlarına yönelik yapılan çalışmalar incelendiğinde prekonsepsiyonel dönemdeki kadınlara yönelik yapılmış bir çalışma olmadığı, gebelere yönelik yapılmış çalışmaların ise çok sınırlı olduğu görülmektedir. Saydam ve ark.'nın (43) riskli gebe kadınlar üzerindeki çalışmalarında SYBDÖ-II genel puan ortalamas1 121,31 $\pm 21,02$, Onat ve Aba'nın (44) çalışmasında ise gebelerin puan ortalamasının 130,7 $\pm 20,0$ olduğu bulunmuştur. Çalışmamızda eğitim ve gelir düzeyi düşük olan, çalışmayan, yetersiz sosyal desteği ve aile içi şiddet öyküsü olan kadınların SYBDÖ-II puan ortalamalarının anlamlı düzeyde düşük olması nedeniyle bu kadınların prekonsepsiyonel dönemde daha fazla risk taşıdıklarını, daha fazla bakım ve desteğe gereksinim duyduklarını ortaya koymaktadır.

$\mathrm{Bu}$ çalışmada elde edilen veriler çocuk sahibi olmak istediği için hastaneye başvuran kadınlardan elde edilmiştir. Dolayısıyla örneklem hastaneye gelen kadınlarla sınırlı olup topluma dayalı olarak seçilmediği için, sonuçlar tüm topluma genellenememektedir.

\section{SONUC}

$\mathrm{Bu}$ çalışmanın sonucunda çocuk sahibi olmayı düşünen kadınların yaş, eğitim düzeyi, aile içi şiddet, sigara dumanına maruziyet, obezite, anemi, folik asit kullanmama gibi prekonsepsiyonel dönemde sağlıklı bir gebelik ve doğum sürecini olumsuz etkileyecek birçok 
risk faktörü taşıdığı bulunmuştur. Bu risk faktörlerinin belirlenerek uygun şekilde yönetilebilmesi için; doğum öncesi bakım hizmetlerinin prekonsepsiyonel dönemden başlatılması ve prekonsepsiyonel dönemde kadınların sağlık taramasından geçirilmesi, bu amaca yönelik olarak sağlık kurumlarında prekonsepsiyonel danışmanlık merkezlerinin kurulması önerilir. Ayrıca prekonsepsiyonel danışmanlığın kurumlarda etkili bir şekilde yürütülebilmesi için uygun prekonsepsiyonel bakım protokollerinin oluşturulması, prekonsepsiyonel sağlık risklerin belirlenmesi için standart ölçme araçlarının geliştirilmesi ve risk taşıyan anne adayları ve yakınlarının bu riskler konusunda bilgilendirilerek uygun merkezlere yönlendirmelerinin yapılması önerilir. Eğitim ve gelir düzeyi düşük olan, çalışmayan, yetersiz sosyal desteği ve aile içi şiddet öyküsü olan kadınlar daha düşük düzeyde sağlıklı yaşam biçimi davranışlarına sahip oldukları için, bu özellikteki kadınların prekonsepsiyonel dönemde öncelikli olarak ele alınması gerektiği söylenebilir.

Yazarların Katkıları: Fikir/Kavram: M.K., Z.G.; Tasarım: M.K., Z.G.; Veri Toplama ve/veya İşleme: M.K.; Analiz ve/veya Yorum: M.K., Z.G.; Literatür Taraması: M.K.; Makale Yazımı: M.K., Z.G.; Eleştirel İnceleme: M.K., Z.G.

\section{KAYNAKLAR}

1. Johnson K, Posner SF, Biermann J, Cordero JF, Atrash HK, Parker CS et al. Recommendations to improve preconception health and health care -United States a report of the CDC/ATSDR. Preconception care work group and the select panel on preconception care. MMWR Recomm Rep. 2006; 55(RR-6): 1-23.

2. Doğaner G, Gölbaşı Z. Prekonsepsiyonel danışmanlık. STED. 2011; 20(5): 215-21.

3. Hadar E, Ashwal E, Hod M. The preconceptional period as an opportunity for prediction and prevention of noncommunicable disease. Best Pract Res Clin Obstet Gynaecol. 2015; 29(1): 54-62.

4. Genuis RA, Genuis SJ. Preconception care: the next frontier for improving maternal-child health care. Public Health. 2017; 149: 57-9.

5. Gottessman MM. Preconception education: Caring for future. J Pediatr Health Car. 2004; 18(1): 40-4.

6. Dunlop AL, Jack BW, Bottalico JN, Lu MC, James A, Shellhaas CS et al. The clinical content of preconception care: Women with chronic medical conditions. Am J Obstet Gynecol. 2008; 199(6 suppl 2): 310-27.

7. Chuang $\mathrm{CH}$, Hillemeier MM, Anne-Marie D, Weisman CS. The Relationship between pregnancy intention and preconception health behaviors. Prev Med. 2011; 53(1-2): 85-8.

8. Baysoy NG, Özkan S. Gebelik öncesi (prekonsepsiyonel) bakım: Halk sağlığı perspektifi. Gazi Med J. 2012; 23(3): 77-90.

9. Ockhuijsen HDL, Gamel CJ, Van Den Hoogen A, Macklon NS. Integrating preconceptional care into an IVF programme. J Adv Nurs. 2012; 68(5): 1156-65.

10. Coşkun A. Prekonsepsiyonel bakım ve danışmanlık: Kadın yaşamındaki yeri ve önemi. Hemşirelikte Eğitim ve Araştırma Dergisi. 2012; 8(3): 8-15.
11. Kermack AJ, Calder PC, Houghton FD, Godfrey KM, Macklon NS. A randomised controlled trial of a preconceptional dietary intervention in women undergoing IVF treatment (PREPARE trial). BMC Women's Health. 2014; 18(14):130.

12. Arslan H, Özkan A. Prekonsepsiyonel dönemdeki kadınların değerlendirilmesi. Zeynep Kamil Tıp Bülteni. 2005; 36(2): 65-71.

13. Cullum AS. Changing provider practices to enhance preconceptional wellness. J Obstet Gynecol Neonatal Nurs. 2003; 32(4): 543-49.

14. Salihu HM, Salinas A. The missing link in preconceptional care: The role of comparative effectiveness research. Matern Child Health J. 2013; 17(5): 776-82.

15. Word Health Organization [Internet]. Preconception care: Maximizing the gains for maternal and child health; 2013. [Updated:2013; Cited: 2019 January 20] Avaible

from:https://www.who.int/maternal_child_adolescent/ documents/preconception_care_policy_brief.pdf.

16. Hurst HM, Linton DM. Preconception care: Planning for the future. J Nurse Pract. 2015; 11(3): 335-40.

17. T.C. Sağlık Bakanlığı [İnternet]. Hemşirelik Yönetmeliğinde Değişiklik Yapılmasına Dair Yönetmelik; 2011. [Updated:2011; Cited: 2015 May 2] Avaible from: https://www.resmigazete.gov.tr/eskiler/2011/04/2011 0419-5.htm .

18. Lee CY, Koren G. Maternal obesity: Effects on pregnancy and the role of pre-conception counselling. J Obstet Gynaecol. 2010; 30(2): 101-6.

19. Bahar Z, Beşer A, Gördes N, Ersin F, Kissal A. Sağlıklı Yaşam Biçimi Davranışları Ölçeği II'nin geçerlik ve güvenirlik çalışması. Cumhuriyet Hem Der. 2008; 12(1): 1-13.

20. Hacettepe Üniversitesi Nüfus Etütleri Enstitüsü, T.C. Cumhurbaşkanlığı Strateji ve Bütçe Başkanlığı ve TÜBİTAK [İnternet]. Ankara: 2018 Türkiye Nüfus ve Sağlık Araştırmas1,. 2019. [Updated:2019; Cited: 2020 May 2] Avaible from:http://www.hips.hacettepe.edu.tr/tnsa2018/rapor /TNSA2018 ana Rapor.pdf.

21. Çatak B, İkiışık H, Kartal SB, Öner C, Uluç HH, Seğmen Ö. İstanbul'da doğum öncesi bakım hizmetlerinin değerlendirilmesi: Toplum tabanlı bir araştırma. Perinatoloji Dergisi. 2012; 20(3): 126-34.

22. Yılmaz T, Dinç H, Bal MD. Gebelerin fetal sağlığın geliştirilmesine yönelik yaptığı uygulamalar. Journal of Academic Research in Nursing. 2015; 1(1): 21-9.

23. Demirbaş H, Kadıoğlu H. Prenatal dönemdeki kadınların gebeliğe uyumu ve ilişkili faktörler. Clin Exp Health Sci. 2014; 4(4): 200-6.

24. Aydemir H, Uyar Hazar H. Düşük riskli, riskli, yüksek riskli gebelik ve ebenin rolü. Gümüşhane Üniversitesi Sağlık Bilimleri Dergisi. 2014; 3(2): 81533.

25. Fullerton JT, Nelson C, Shannon R, Bader J. Prenatal care in the Paso del Norte border region. Jour Perinatol. 2004; 24(2): 62-71.

26. Usturalı Mut AN, Öcek ZA, Yücel U, Çiçeklioğlu M, Eden E. İzmir-Bornova'da gebelerin ağız-diş sağlığ hizmeti gereksinimi ve bu hizmetlerden yararlanma 
düzeyinin sosyoekonomik değişkenlerle ilişkisi. Dokuz Eylül Üniversitesi Tıp Fakültesi Dergisi. 2014; 28(3): 93-103.

27. Koyun A, Taşkın L, Terzioğlu F. Yaşam dönemlerine göre kadın sağlığı ve ruhsal işlevler: Hemşirelik yaklaşımlarının değerlendirilmesi. Psikiyatride Güncel Yaklaşımlar. 2011; 3(1): 67-99.

28. Akdolun Balkaya N, Vural G, Eroğlu K. Gebelikte belirlenen risk faktörlerinin anne ve bebek sağlığ açısından ortaya çıkardığı sorunların incelenmesi. Düzce Üniversitesi Sağlık Bilimleri Enstitüsü Dergisi. 2014; 4(1): 6-16.

29. Suarez L, Cardarelli K, Hendricks K. Maternal stress, social support, and risk of neural tube defects among Mexican Americans. Epidemiology. 2003; 14(5): 61216.

30. Kabaran S, Samur G. Maternal obezite ve gebelik. Beslenme ve Diyet Dergisi. 2010; 38(1-2): 45-52.

31. Ferrari RM, Siega-Riz AM, Evenson KR, Moos MK, Carrier KS. A qualitative study of women's perceptions of provider advice about diet and physical activity during pregnancy. Patient Educ Couns. 2013; 91(3): 372-77.

32. Körükçü Ö, Kukulu K. Obezitenin üreme sistemi üzerine etkisi. TAF Preventive Medicine Bulletin. 2011; 10(2): 231-38.

33. Taşcı Duran E, Atay E, İmer B. Gebelikte egzersiz uygulamaları: Neden? Nasıl? SSTB. 2013; 6(3): 6374.

34. Atalay S, Dağhan Ş, Kalkım A. Gebelerin pasif içiciliğin fetüs ve yenidoğan sağlığına etkileri konusundaki bilgileri. STED. 2014; 23(1): 16-24.

35. Durualp E, Bektaş G, Ergin D, Karaca E, Topçu E. Annelerin sigara kullanımı ile yenidoğanın doğum kilosu, boyu ve baș çevresi arasındaki ilișkinin incelenmesi. Ankara Üniversitesi Tip Fakültesi Mecmuas1. 2011; 64(3): 119-26.

36. Honkala S, Al-Ansari J. Self-reported oral health, oral hygiene habits, and dental attendance of pregnant women in Kuwait. J Clin Periodontol. 2005; 32(7): 809-14.

37. Quinn LA, Thompson SJ, Ott MK. Application of the social ecological model in folic acid public health initiatives. J Obstet Gynecol Neonatal Nurs. 2005; 34(6): 672-81.

38. Jack BW, Atrash H, Bickmore T, Johnson K. The future of preconception care: A clinical perspective. Womens Health Issues. 2008; 18(6): 19-25.

39. Mitchell AA, Gilboa SM, Werler MM, Kelley KE, Louik C, Hernandez-Diaz S. Medication use during pregnancy, with particular focus on prescription drugs: 1976-2008. Am J Obstet Gynecol. 2011; 205(1): 51.e1- 51.e8.

40. Öztürk Z. İlaç kullanan gebeye yaklaşım: Teratojenite riski ve danışmanlık hizmeti. STED. 2014; 23(5): 201-5.

41. Brabin BJ, Hakimi M, Palletier D. An analysis of anemia and pregnancy-Related maternal mortality. The Journal Nutrition. 2001; 131(2S-2): 604-14.

42. Ural A. Gestasyonel diabetes mellitus ve sağlıklı yaşam biçimi davranışları. DÜ Sağlık Bil Enst Derg. 2016; 6(2): 120-27.
43. Saydam BK, Bozkurt BÖ, Hadımlı AP, Can HÖ, Soğukpınar N. Riskli gebelerde öz-bakım gücünün sağlıklı yaşam biçimi davranışlarına etkisinin incelenmesi. Perinatoloji Dergisi. 2007; 15(3): 13139.

44. Onat G, Aba YA. Health-promoting lifestyles and related factors among pregnant women. Turk J Public Health. 2014; 12(2): 69-79. 